nguistics today and,

tion

ıd Robert E. Remez mtax, Volumes $\mathrm{I}-\mathrm{V}$ ıd Henk van

'English

e and Bettelou Los istics

it McMahon

ies

nuna Kachru, and

inguistics

id Francis M. Hult istics

lael R. Perkins, ard

sole Studies

and John Victor

hing

ud Catherine J.

act

Speech Disorders ole Müller, and

stics and Natural

ris Fox, and

Ilobalization

istics

os

\title{
The Handbook of Language Socialization
}

Edited by

Alessandro Duranti, Elinor Ochs, and Bambi B. Schieffelin

\section{(\$)WILEY-BLACKWELL}

A John Wiley \& Sons, Ltd., Publication 
This edition first published 2012

2012 Blackwell Publishing Limited

Blackwell Publishing was acquired by John Wiley \& Sons in February 2007. Blackwell's publishing program has been merged with Wiley's global Scientific, Technical, and Medical business to form Wiley-Blackwell.

Registered Office

John Wiley \& Sons Ltd, The Atrium, Southern Gate, Chichester, West Sussex, PO19 8SQ, United Kingdom

Editorial Offices

350 Main Street, Malden, MA 02148-5020, USA

9600 Garsington Road, Oxford, OX4 2DQ, UK

The Atrium, Southern Gate, Chichester, West Sussex, PO19 8SQ UK

For details of our global editorial offices, for customer services, and for information about how to apply for permission to reuse the copyright material in this book please see our website at www.wiley.com/wiley-blackwell

The right of Alesandro Duranti, Elinor Ochs, and Bambi B. Schieffelin to be identified as the authors of the editorial material in this work has been asserted in accordance with the UK Copyright, Designs and Patents Act 1988

All rights reserved. No part of this publication may be reproduced, stored in a retrieval system, or transmitted, in any form or by any means, electronic, mechanical, photocopying, recording or otherwise, except as permitted by the UK Copyright, Designs and Patents Act 1988, without the prior permission of the publisher.

Wiley also publishes its books in a variety of electronic formats. Some content that appears in print may not be available in electronic books.

Designations used by companies to distinguish their products are often claimied as trademarks. All brand names and product names used in this book are trade names, service marks, trademarks or registered trademarks of their respective owners. The publisher is not associated with any product or vendor mentioned in this book. This publication is designed to provide accurate and authoritative information in regard to the subject matter covered. It is sold on the understanding that the publisher is not engaged in rendering professional services. If professional advice or other expert assistance is required, the services of a competent professional should be sought.

Library of Congress Cataloging-in-Publication Data

The handbook of language socialization / edited by Alessandro Duranti, Elinor Ochs, and Bambi B. Schieffelin.

p. cm. - (Blackwell handbooks in linguistics)

Includes bibliographical references and index.

ISBN 978-1-4051-9186-9 (alk. paper)

1. Language acquisition-Social aspects. 2. Socialization. 3. Language and languages-

Study and teaching. I. Duranti, Alessandro. II. Ochs, Elinor. III. Schieffelin, Bambi B.

P118.H3485 2012

$306.44-\mathrm{dc} 22$

A catalogue record for this book is available from the British Library.

This book is published in the following electronic formats: ePDFs 9781444342871;

Wiley Online Library 9781444342901; ePub 9781444342888; Mobi 9781444342895

Set in 10/12pt Palatino by Toppan Best-set Premedia Limited

Printed and bound in Singapore by Markono Print Media Pte Ltd

List of Illustration: Notes on Contribt: Acknowledgment:

1 The Theory o. ELINOR OCHS

Part I Interactio

2 The Cultural PENELOPE BRI

3 Preverbal Inf; AkIRa TaKad

4 Language Sor LOURDES DE

\section{Part II Socializa}

5 Rethinking B OLGA SOLOM

6 Local Theorif AMY PAUgh

7. Language So ADRIENNE Li

8 Language So PegGy J. MIL

9 Language So LESLIE C. Mc

10 Literacy Soci LAURA STERI

11 Language Sc TANXA STIVE 
demic

anguage and Oxford: Oxford

apragmatic sgy of impolite al of Linguistic

Essential Jew York:

eativity and American alization into $\mathrm{n}$ A. Reyes and w English: opology of Asian Jew York:

$t$ episodes in aking of eraction. -100 . Bunka (Language lami Shoten. in Introduction to bridge

rpretation of ipeech situation, zultural

.1-48.

xism and the Matejka and I. dge, MA:

egeo, D. W. reating routines iguage effelin and $\mathrm{E}$. alization Across ;e: Cambridge

and Literature. y Press.

\section{Peer Language Socialization}

\section{MARJORIE H. GOODWIN AND AMY KYRATZIS}

\section{Introduction}

An essential feature of work in the language socialization paradigm is examining how in becoming competent participants of their social group children (or other members) are socialized through language and to use language (Kulick and Schieffelin 2004: 350). Learning appropriate affective stances is an important dimension of becoming a competent social group member, as studies of language socialization are fundamentally concerned with how it is that novices acquire a habitus or ways of being in the world (Kulick and Schieffelin 2004: 249); rather than asking how societies vary cross-culturally, the focus in language socialization studies is on how specific affective alignments or positions come into being and are negotiated (Kulick and Schieffelin 2004: 351; see also Cook, this volume). Analysis of the acquisition of particular practices over time is based on extensive longitudinal ethnographic study of specific embodied language resources. Participants in the process of language socialization mutually shape one another; thus, in the family, children as well as parents are 'mutual apprentices' (Pontecorvo, Fasulo, and Sterponi 2001) to one another.

Seminal studies in language socialization (Kulick 1992; Ochs and Schieffelin 1984; Schieffelin and Ochs 1986) have addressed how more accomplished participants socialize novices, as, for example, in parent-child or teacher-student interaction. Work by Schieffelin (1990) and others (Burdelski 2010, this volume; Clancy 1986; Rabain-Jamin 1998) has examined prompting as an important resource for 'socialization to use language' (Schieffelin and Ochs 1986: 163), as well as socialization into particular relationships. In Kaluli a specific grammatical form, a:la:ma

The Handbook of Language Socialization, First Edition. Edited by Alessandro Duranti, Elinor Ochs, Bambi B. Schieffelin.

(C) 2011 Blackwell Publishing Ltd. Published 2011 by Blackwell Publishing Ltd. 
or 'say like that,' is used to help establish the gender identity of girls. Generational identity of young children is established through the term o:mina, meaning having chewed, give' (Ochs and Schieffelin 2006: 183). In Samoa, the term sau helps to build the directive meaning 'to come,' establishing the identity of the speaker as relatively higher status than the addressee.

Instead, here our focus is on how child participants, either members of a peer group or sibling multiage group - socialize one another. Western-influenced notions of 'peer groups' have conceptualized children's groups as consisting of same-age peers who are not related to one another. However, many children's groups in neighborhoods and nonschool settings (Goodwin 1990; Thorne 1993) in Western cultures, and in non-Western cultures in which older children spend large periods of the day caring for younger kin (de León 2007; Reynolds 2002; Rogoff 1981; see Goodwin and Kyratzis 2007 for a review), do not consist of same-age members or children unrelated to one another. We acknowledge that both 'peer groups' and 'sibling-kin groups' are important arenas where language socialization occurs, and include both in the scope of this chapter.

Children's negotiations of how they stand vis-à-vis one another - that is, their 'identities-in-interaction' (Antaki 1994; Antaki and Widdicombe 1998) - are made relevant in the midst of their naturally occurring conduct with one another. In the course of talk, as Pomerantz and Mandelbaum (2005: 153) argue, participants achieve and renew their relationships with one another through the act of 'talking and acting in ways that are recognizably bound with relationship categories.' In this chapter we investigate a number of systematic practices and resources through which children in concert with one another build the phenomenal and social worlds they inhabit as the situated product of interactive practices: evaluating their playmates, ascribing particular categorizations to one's interlocutors, creating differentiation and hierarchy, constructing a pretend world, and using practices of language alternation.

While evaluating group members through storytelling, assessments, insults, or categorizations of person, children take up either common or divergent stances towards the target, socializing appropriate forms of behavior. Such practices thus lie at the heart of processes of achieving intersubjective understanding (Goodwin and Goodwin 1987). In order to come to terms with these practices, we investigate evaluative commentary as 'well as members' categories (which often carry an affective valence) that occur in the midst of such activities. We also explore how children utilize members' categories, as well as directives, as resources for building social organization in pretend play, and how children use features of different registers, voices, and genres during play as means to both explore and comment on social roles, categories, and relationships from the adult world and to negotiate social order (see also Aronsson, this volume). Finally, we examine how children growing up in multilingual communities make use of practices of language alternation to build opposition and aligruments as well as to define 'social places' (Schieffelin 2003: 158) for their language varieties during play.

\section{Evaluative Comm}

In the midst of talk, pee commentary to one anot in their larger social uni guistic practices such : Pomerantz 1984), and redefine the social situa making evaluative com bound activities' or ' $\mathrm{n}$ taking up stances wit' they not only locate an ate moral behavior, but one another in the 1999,2002 ) - an aggre ways of talking, belit 1992: 464).

\section{Gossip}

Within storytelling, ] in the local social $g$ Goodwin (1990) anc hood girls aged bet two against one th make use of multip! cal stories, and har party that leads to $]$ action against the back. These are in cerning someonet is thought to rest interactions, deal meeting between

Researching L 181) discusses 'ta denouement: it third party unfa or imaginary $\mathrm{v}$ : that Shuman (19 American, and I the role of $\mathrm{t}$. critical. Shuma 
girls. Generational $a$, meaning having ? term sau helps to $y$ of the speaker as

\section{members of a peer} Nestern-influenced ps as consisting of I, many children's 90; Thorne 1993) in hildren spend large nolds 2002; Rogoff 'onsist of same-age lge that both 'peer language socializa-

ther - that is, their se 1998) - are made one another. In the argue, participants $\mathrm{h}$ the act of 'talking ship categories.' In $A$ resources through omenal and social ractices: evaluating interlocutors, creat$\mathrm{Id}$, and using prac-

isessments, insults, imon or divergent ehavior. Such practive understanding ith these practices, ' categories (which such activities. We ell as directives, as and how children 5 play as means to relationships from sson, this volume). communities make and alignments as language varieties

\section{Evaluative Commentary}

In the midst of talk, peers police the local social landscape and make evaluative commentary to one another with respect to what they consider the valued signs in their larger social universe - ones that are linked to social status. Through linguistic practices such as gossip, assessments (Goodwin and Goodwin 1987; Pomerantz 1984), and storytelling, group members continuously define and redefine the social situation and hold one another accountable to it. Participants making evaluative commentary link what Sacks $(1972,1995 b)$ has called 'categorybound activities' or 'members' categories' with the target being assessed. By taking up stances with respect to the target or stance object (Du Bois 2007), they not only locate and reference the peer group's notion of culturally appropriate moral behavior, but also negotiate their alignments to one another and position one another in the local social group or community of practice (Bucholtz 1999,2002 ) - an aggregate of people who develop shared 'ways of doing things, ways of talking, beliefs, values, power relations' (Eckert and McConnell-Ginet 1992: 464).

\section{Gossip}

Within storytelling, play, and gossip, peers learn appropriate ways of interacting in the local social group (Eder 1995; Goodwin 1990; Loyd 2011; Shuman 1986). Goodwin (1990) analyzes the 'he-said-she-said' gossip event in which neighborhood girls aged between 7 and 12 tell stories leading to future confrontations of two against one that reorganize and realign the local social organization. Girls make use of multiple types of stories - instigating stories, retold stories, hypothetical stories, and harvested parallel stories - to elicit a statement from an offended party that leads to her confronting an offending party (Goodwin 1990: 187) to take action against the offense of having said something about someone behind her back. These are important ways of dealing with real and imagined offenses concerning someone having put herself above others; failure to confront one's offender is thought to result in loss of social face. The focus is on both prior and future interactions, dealing with what someone in fact said, or would say in a future meeting between the offended and offending parties.

Researching Latina gang girls in Northern California, Mendoza-Denton (2008: 181) discusses 'talking shit,' a form of gossip that has an optional confrontational denouement: 'it is either a third-person account where the speaker portrays the third party unfavorably or a narrative where one brags about one's own factual or imaginary victory against an absent one.' In the he-said-she-said disputes that Shuman $(1986,1992)$ examined among a group of African American, European American, and Puerto Rican inner-city junior high-school students in Philadelphia, the role of the instigator, rather than the original offending party, was critical. Shuman states (1992: 140): 'In many cases the message-bearer was held 
responsible for instigating the conflict, and the antagonisms shifted from the original offense to a challenge against the person who was not entitled to talk about someone else's offense.' In high-school years and beyond, responsibility for instigating becomes a key issue when gossip turns into 'rumor' (Morgan 2002: 60).

Evaldsson (2002), investigating gossip among working-class preadolescent Swedish boys, finds that boys' alignments of two against one (against girls as well as boys) result in confrontations in the present encounter rather than in a future one. As in the Maple Street, Philadelphia boys' stories studied by Goodwin (1990), the child animated as principal character in a telling is present. Through practices such as format tying, boys demonstrate highly collaborative intimate stances in support of talk by a group member about someone who positions her/himself above others. Evaldsson (2002: 211) finds that the participant structure of the gossip telling itself simultaneously allows the boys to solicit support, seek affiliation, and strengthen solidarity - features prominent in all-female groups.' Because the party being talked about in a degrading fashion is present, he may counter the negative assessment; nevertheless, each successive counter by the target leads to further confirmations by others of their collective alignment against him. Boys thus can establish relations of power and hierarchy in the midst of collectively showing support in aligning against a present target.

Evaldsson's work problematizes easy gender dichotomies. However, offences among boys do not concern what an intermediary party reportedly said behind one's back, as occurs in girls' groups. Rather, the social categories that are invoked deal with male cultural concerns: 'anxieties about being excluded, associated with physical vulnerability, emotional weakness, and cowardice' such as crying, sulking, wetting one's pants, or calling for a teacher's intervention (Evaldsson 2002: 199).

\section{Assessments}

Bucholtz (2007: 378) has noted that discernment (Bourdieu 1984), or the ability to distinguish between what is desirable and what is not, is fundamental to groups as a way to index social status. Goodwin's (2006) fieldwork among elementaryschool girls in Los Angeles aged between 10 and 12 found that peers hold one another accountable for recognizing the meaning of signs that index wealth, such as cars that are luxurious, foreign travel, or elite sports, and being able to produce appropriate moves that show understanding of relative value within a language game.

Newon (2006), studying assessments (Goodwin and Goodwin 1987; Goodwin 2007; Pomerantz 1984) during storytelling among a multiethnic middle-class group of 14-16-year-old cheerleaders in an all-girl Catholic school in suburban California, observed that girls create their own local culture by defining what to aspire to and what to avoid. Girls evaluated body image, physical and mental ability, maturity, and popularity. In small groups, girls who produced selfdeprecations - negative assessments about themselves - received in response moves of disagreement (supportive commentary about the initial speaker).
However, in large framed with laugh

Forms of discer studied a multicul: computer club. H $\epsilon$ ties online as they assessments that $v$ style. Eckert's (198 rations) and burns ban Detroit found Mendoza-Denton complex ideologi dress, makeup, $k$ Analyzing the lar three Silicon Vall 'popular' styles $v$ Bucholtz (2011) e: tural styles of pre European Americ in the San Francis

Looking at te southwest Germi romantic relation deal with relativ and repulsion, si and the larger crc (2003: 386) notes which she argues the accomplishm (2003: 386) maint to the receiver as session and exer Critiques of $g$ that ranks them $\mathrm{i}$ - ('think she popu' when critiquing trendy clothing, date.' The prefac read the intentio this case, wearir making such cla

Spreckels (20 during their leis someone, with thinks he's listes 
shifted from the tt entitled to talk responsibility for Uorgan 2002: 60). iss preadolescent ainst girls as well $r$ than in a future - Goodwin (1990), Through practices timate stances in ions her/himself structure of the pport, seek affiligroups.' Because he may counter $y$ the target leads gainst him. Boys st of collectively

owever, offences edly said behind that are invoked , associated with such as crying, ttion (Evaldsson

or the ability to rental to groups ong elementarypeers hold one lex wealth, such able to produce thin a language

1987; Goodwin ic middle-class rol in suburban efining what to ical and mental produced selfed in response nitial speaker).
However, in larger groups negative assessments about nonpresent girls, often framed with laughter, were frequently ratified.

Forms of discernment have also been investigated by Henderson (2009), who studied a multicultural group of tweens aged between 10 and 12 in an after-school computer club. Henderson found that tweens explored a range of diverse identities online as they played 'Whyville.' They styled online avatars through forms of assessments that were used to evaluate 'the good body' and a savvy Los Angeles style. Eckert's (1987) study of jocks (students oriented towards middle-class aspirations) and burnouts (students identifying with working-class culture) in suburban Detroit found polar differences in how adolescents style forms of coolness. Mendoza-Denton examined norteña and sureña, embodied styles that index complex ideologies through multiple semiotic resources of difference (music, dress, makeup, body image, and phonetic pronunciations) (2008: 208, 212). Analyzing the language and culture of South Asian American teens or 'Desis' in three Silicon Valley high schools, Shankar (2008) compares hip, cosmopolitan 'popular' styles with what popular teens term 'FOB' ('fresh-off-the-boat') styles. Bucholtz (2011) examined the semiotic practices used to construct the youth cultural styles of preppy mainstream white hip hop fans, and nerds among youth of European American descent at Bay City High, un urban multiracial public school in the San Francisco Bay Area.

Looking at telephone conversations between 14-16-year-old girlfriends in southwest Germany, Kotthoff (2010) found the valued signs of these girls were romantic relationships with boys. She analyzed how girls socialize one another to deal with relatively unstable romantic contacts, characterized by both attraction and repulsion, simultaneously positioning themselves in their friendship groups and the larger cross-sex social world as they discuss these relationships. As Eckert (2003: 386) notes, positioning can also be accomplished through compliments, which she argues constitute the 'verbal means by which girls monitor progress in the accomplishment of new norms of feminine behavior and adornment.' Eckert (2003: 386) maintains that 'sincere compliments to players in the market add value to the receiver as evidence of her quality, and to the giver as evidence of her possession and exercise of cultural knowledge.'

Critiques of girls who imagine themselves as occupying a particular category that ranks them above others are constructed through the use of mental-state verbs ('think she popular' or 'think she cute'). For example, among a Los Angeles clique, when critiquing a girl named Janis for bragging about her Spice Girls artifacts and trendy clothing, Aretha stated, 'Janis thinks she's popular because she stays up to date.' The preface 'she think' displays how the girls, as cognitively complex actors, read the intentionality or status claims that underlie the use of particular signs (in this case, wearing clothes that are trendy) and assess the character of the person making such claims.

Spreckels (2008), conducting a two-year study with German adolescent girls during their leisure activities, discusses a similar framing for complaints against someone, with utterances such as 'He thinks he's $X$ just because of $Y^{\prime}$ : 'Now he thinks he's listening to rock music just because he listened to ACDC somewhere.' 
Music is important in the culture of German adolescents (and hence in identity construction). Knowledge of musical style (e.g. gangsta and hip hopper) is used to index those who are hip (affiliate with the youth culture) from those who are not. Such framings as 'he thinks he's doing $X^{\prime}$ ' are often used to project the category of someone who is a 'wannabe' (as in 'wannabe hippie' or 'wannabe film star') and cannot appropriately occupy the category. Similarly, Henderson (2009), in her study of Southern California tweens who construct virtual-world identities while playing 'Whyville,' noted distinctions that children made between groupies ('emos') and actual band members (someone who is 'rockish').

\section{Ritual insult and negative assessments}

Evaldsson (2005: 765-6) reviews work on ritual insulting (talk that concerns a pejorative attribute of the target not known as literally true), including alternative ways that participants sequence next turns, pointing out that there is always a danger that the boundary between playful and real aggression will begin to blur' (Evaldsson 2005: 765). As physical fights are a possible next move to personal insults (Kochman 1983; Labov 1972), jocular abuse is used to prevent aggression (Eder 1995; Rampton 1995) while laughter breaks tension. Evaldsson (2005: 769) sees insult as emerging from mocking, ridiculing, and gossiping, resulting from games as well as isolated insult sequences. Evaldsson (2005: 770) argues that fighting back and 'being able to take it' are important to everyday masculine experience (Danby and Baker 1998; Eder 1995; Morgan 2002; Thorne 1993), promoting 'toughness' and competition (Evaldsson 2002; Willis 1981). Studying female peer groups in the Quartieri Spagnoli (inner city Napoli), Loyd (2011) found that 5-12-year-old girls construct their moral and social order in everyday performances of argumentation. In response to living in a world where peers constantly monitor and police each other in attempts to gain respect and rise in their dominance hierarchies, girls learn the art of quick, theatrical, witty comebacks to gain leverage in everyday relations.

In her discussion of 'playing the dozens,' a form of ritualized (Labov 1972) insult, Morgan (2002: 58) finds that a particular format is used: 'Your mother (is) so adjectival ... (that),' where the adjectival phrase is followed by a clause. Examples include 'Your mother is so fat that when she sits on a quarter she gets two dimes and a nickel' and 'Your mother is so old that when she read(s) the Bible she reminisces' (Morgan 2002: 59). Insults not only allow practice of verbal skill; through insults peers learn the cultural categories that are relevant to their social group.

In the activity of 'clowning,' older adolescent Latina: gang girls studied by Mendoza-Denton (2008: 187) make use of the structure 'Your (possession/relation of the interlocutor) is so (unflattering adjective) that (outrageous result)' to make comparisons with one another; for example, 'Your mama is so tiny that she could hang-glide on a dorito.' The retort to a clowning insult must be a funnier, more creative and more daring insult than the first, improvised in the local interaction and targeting the co-participant's undesirable features. This practice is related to ritual or mock insults in African American English as well as the vernacular Mexican Spanish verbal art form albur, which typically entails double entendre

rhyming references 188); for example, $G$ you?') Among Fres which makes use of also to tease and fli

Forms of social a are responded to $W$ class African Ame someone of a predo target of return $\mathrm{CO}$ described Angela as woman, unable to : Goodwin and Alin such insult sequen African American ₹ 'Clueless' Valley gir: roll, suck teeth, an

Children make category-bound ac transgressors. Neg girls' groups, incli behind people's ba (not having Poken generally), having being labeled a 'G. in school) were $r$ immigrant backg. (Evaldsson 2005: : 1967: 237). Evald which multiparty to ratify particula new linked evalu disgusting. Evalc categories withou tive person descr point to implicit accomplish their

\section{Membershi}

Goodenough's (] idea that culture cedures, much 1 Harvey Sacks' fr egorization devi 
nce in identity oper) is used to se who are not. ct the category labe film star') n (2009), in her dentities while ween groupies

hat concerns a ling alternative ere is always a $\downarrow$ will begin to ove to personal rent aggression son (2005: 769) resulting from gues that fightsculine experi93), promoting ng female peer 11) found that yday performeers constantly : in their domirebacks to gain

\section{A (Labov 1972)}

$r$ mother (is) so ause. Examples gets two dimes Bible she remil skill; through social group. irls studied by ession/relation 'esult)' to make $r$ that she could a funnier, more ocal interaction ice is related to the vernacular ouble entendre rhyming references with 'ambiguous sexual innuendo' (Mendoza-Denton 2008: 188); for example, Guera, guera, ¿Quién te encurea? ('Blondie, Blondie, who'll disrobe you?') Among French adolescents of Algerian descent, parental name-calling, which makes use of potentially face-threatening acts, is used not only to insult but also to tease and flirt (Tetreault 2010).

Forms of social aggression rather than verbal play can occur when ritual insults are responded to with personal insults. Goodwin (2006) found that a workingclass African American girl (Angela) who directed a playful ritual insult to someone of a predominantly upper-middle-class clique could quickly become the target of return comments portraying being poor as a degraded status: girls described Angela as unable to find a job when she grew up, working as a cleaning woman, unable to afford braces, needing to be on welfare, and without friends. Goodwin and Alim. (2010) describe practices of 'transmodal stylization' during such insult sequences. A member of the clique openly mocked what the targeted African American girl was saying by using features of talk associated with white 'Clueless' Valley girls while simultaneously producing stereotypical gestures (neck roll, suck teeth, and eyeball roll) associated with black 'ghetto' girls.

Children make use of locally relevant and culturally specific categories and category-bound activities to provide negative depictions of those positioned as transgressors. Negative category-bound activities in Evaldsson's (2007) studies of girls' groups, including fighting, blaming, exploiting others, lying, and talking behind people's backs, were associated with the category 'bad friend.' Being poor (not having Pokemon cards, wearing old clothing, or lacking material goods more generally), having limited Swedish language proficiency, dressing like a girl, and being labeled a 'Gypsy' (rather than the in-group label 'Romany' commonly used in school) were negative person descriptors among boys of working-class or immigrant background in multiethnic elementary school groups in Sweden (Evaldsson 2005: 771). Such terms were used during character contests (Goffman 1967: 237). Evaldsson. (2005) closely examines the sequential environments in which multiparty consensus (see also Evaldsson 2002; Goodwin 1990) is created to ratify particular depictions, through upgrades, laughter, recycles, repetitions, new linked evaluations, and so on that frame the acts of the offending party as disgusting. Evaldsson's point is that we cannot ascribe meaning to members' categories without conducting extended fieldwork. Assessment adjectives, pejorative person descriptors, and negative categorizations of activities and actors all point to implicit cultural values that the children invoke and orient to as they accomplish their alignments to one another in the interaction.

\section{Membership Categorizations}

Goodenough's (1965) notion of identity as situated, local, and occasioned and his idea that culture consists of an underlying body of structures, practices, and procedures, much like the grammar of a language (1981: 102-3), was influential in . Harvey Sacks ${ }^{\prime}$ formulation of notions of identity selection and membership categorization devices. Sacks (1972) argued that membership categorization devices 
provide ways of allowing people to understand categories as sets or standardized relational pairs (e.g. mother and child belong to the category 'family'). Membership categorizations consist of particular actions or category-bound activities that are constitutive of a specific category; members' categories are what people make use of to describe events in the world.

Games, Sacks (1995a) argued, provide ways of 'mapping members' or locating participants in relevant occasion-specific categories. Applying Sacks' notion of membership categorization to analysis of children's games and pretend play, Butler and Weatherall (2006) studied six-to-seven-year-old children in two innercity Australian schools during recess. They examined members' categories in broadcasting games, playing 'treasures' (a game that involved follow-the-leader - with the leader having the right to judge what counted as real treasure, where the treasure was, and the proper order of game events and players (2006: 455)), playing families, and 'fairy club.'

\section{Ethnography and studies of members' categorizations}

Current work on talk-in-interaction, which combines ethnographic studies with close sequential analysis of conversation and membership categorization devices, permits investigation not only of how the local situated activity is organized but also how actions and stances (du Bois 2007; Jaffe 2009) taken across a range of interactions are consequential for participants' lives and help to construct more enduring forms of social organization. Through examining stance-taking, we can come to grips with the concerns that deeply animate participants. Evaldsson (2007) explored how 'relationship work' is accomplished among a multiethnic group of immigrant Swedish girls aged between 11 and 12. She was concerned with moral ordering by peers, achieved through both. sequential analysis and category membership. Challenging a unitary view of female morality, Evaldsson found that one member of the group of girls she studied was repetitively subject to being made accountable for negative category-bound activities (fighting, blaming, exploiting others, lying, talking behind people's backs, and being disloyal, insane, and friendless). The targeted girl openly resisted responsibility through denials, justifications, recyclings, substitutions, and counter-accusations, which only intensified attributions of negative category membership ('bad friend') and eventually resulted in her being friendless rather than mitigating conflict.

Evaldsson (2005: 764) has argued that, by combining analysis of members' social categories with an examination of talk-in-interaction, we can explore the constitutive role of talk for local social organization and how issues associated with wider social structures and discourses can be located, observed, and described within situated action.' Person formulations are articulated in concert with what Zimmerman (1998: 90-1) has discussed as situated identities that emerge out of the particular action at hand. Goodwin (2011) found that gendered terms such as 'girl' and 'boy,' for example, can be mobilized both in the midst of disputes (as a component of a turn taking up an oppositional stance to a prior move interpreted as argumentative - in essence, an epithet) as well as in mutual congratulatory exclamations during performed). Tarim (2 in Turkey orienting 1 They invoked the $t$ accountable to them

In her analysis of Evaldsson (2005) fin children and schoo insults. She argues (category-bound act tute and reflect cont cific group and sett assessments, such tl Swedish, ethnicity, : the frame of insults. in a negative light in a particular way of the school. Indeer tions of an 'unmo conversation-analys edged or unacknow

\section{Members' cate}

Several researcher Marx, and Wade 2 categorization (Sac Enacting stratified stituting hierarchi social order of th display 'best frier twins married to twin brothers pror while simultaneou also constructing a five-year-old girls Weatherall 2006).? 'news reporter/ar lead announcer $/ \mathrm{r}$ allocation enabled

Game roles ar structing positiv displaying affilia (sports announ children can ind 
or standardized

$\Rightarrow$.). Membership tivities that are eople make use

sers' or locating acks' notion of 1 pretend play, an in two inner$\mathrm{s}^{\prime}$ categories in llow-the-leader treasure, where ers (2006: 455)),

\section{ions}

hic studies with rization devices, is organized but cross a range of , construct more e-taking, we can sants. Evaldsson ig a multiethnic a was concerned tial analysis and rality, Evaldsson petitively subject ivities (fighting, 5 , and being dised responsibility inter-accusations, ;hip ('bad friend') zating conflict. isis of members' : can explore the issues associated ed, and described oncert with what lat emerge out of red terms such as of disputes (as a move interpreted al congratulatory exclamations during assessment sequences (where a stance of affiliation is being performed). Tarım $(2007,2008)$ similarly observed four- and five-year-old children in Turkey orienting to gendered terms such as 'girl' and 'boy' during peer play. They invoked the terms to index category-bound behaviors and hold peers accountable to them during group disputes.

In her analysis of categorizations among a multiethnic peer group in Sweden, Evaldsson (2005) finds it essential to make use of ethnographic knowledge of the children and school setting to understand children's categorizations during insults. She argues that 'categorizations are bound up with particular actions (category-bound activities) or characteristics (natural predicates) that both constitute and reflect conventional expectations of normative behaviours within a specific group and setting' (2005: 768). Evaldsson found that, in making negative assessments, such things as possessions, clothing, limited language proficiency in Swedish, ethnicity, and sexuality were important topical concerns relevant within the frame of insults. In order to understand why particular aspects of self were viewed in a negative light - for example, why Swedish language proficiency was evaluated in a particular way - she found it important to understand the local language ideology of the school. Indeed, Stokoe and Smithson (2002: 84) argue that, contrary to accusations of an "unmotivated "analytic mentality", researchers working within the conversation-analysis framework 'use their background knowledge, either acknowledged or unacknowledged, in the process of doing analysis.'

\section{Members' categorizations in pretend play}

Several researchers (Berentzen 1984; Goodwin 2011; Griswold 2007; Kyratzis, Marx, and Wade 2001; Kyratzis 2007) have noted children's use of membership categorization (Sacks 1995a) for organizing local social order during pretend play. Enacting stratified roles in pretend play provides children with resources for constituting hierarchical relationships among themselves and constructing the local social order of the peer group. For example, Goodwin (2008) noted how girls display 'best friend' relations through roles they select in pretend play, such as twins married to twins. The membership categorization devices twin sisters and twin brothers provided a resource for two girls to display alignments to one another while simultaneously differentiating themselves from other clique members, thereby also constructing asymmetrical relationships. Kyratzis (2007) observed a peer group of five-year-old girls who constructed their pretend play as news reporting (Butler and Weatherall 2006). Through their labels and interaction, they oriented to the category of 'news reporter/announcer' and divided this category into hierarchical levels, with a lead announcer/news reporter and subordinate announcers. This role division and allocation enabled the children to construct distinctions in their own local social order.

Game roles and categories can also provide children with resources for constructing positive alignments. For example, Hoyle (1998) described two boys displaying affiliation to one another through aligning to one another's characters' (sports announcer) speech in pretend play. In peer pretend play, young children can index their social alignments to one another indirectly through the 
membership categorizations they orient to in their play. By indexing an orientation to playing 'getting married' (Sheldon 1996), for example, two preschool girls were able to display an orientation to one another and were simultaneously able, consistently with the frame, to exclude a third girl by telling her that she was the baby brother but that she wasn't born yet.

\section{Accomplishing Local Social Order with Directives in Pretend Play}

Pretend play presents children with several resources for constructing social organization within the peer group (Goodwin 1993) in addition to membership categorizations. As Ervin-Tripp (1996: 33) has argued, 'Children's subtle observation of the background features of adult speech is never revealed so fully as in their role play.' Directives provide one major way through which children realize positions of dominance and submission between characters (Goodwin 1990: 127). (See also Andersen 1990; Aronsson and Thorell 1999; Corsaro 1985; Ervin-Tripp, Guo, and Lampert 1990; Evaldsson and Tellgren 2009; Mitchell-Kernan and Kernan 1977).

In pretend play, children show a keen awareness of how different social identities can be presented as distinct 'voicings' (Goldman 1998: 155). Away from adult presence, children 'exploit their understandings of [...] power hierarchies at familial, local, national, and global levels' (Paugh 2005: 65) and in so doing 'create alternative social realities in which THEY hold the positions of authority, power, and control' (Paugh 2005: 65). Goodwin (1990) showed how the African American working-class girls she observed enacted asymmetry in their own social relationships through directives in games of 'house.' While girls enacting the role of mother delivered imperatives loudly with emphatic stress to their 'children,' girls playing the role of subordinates made excuses to the girls enacting the role of mother, thereby ratifying the right of the girls in the mother role to command them (Goodwin 1990: 127-9).

Subsequent ethnographic studies showed girls' agentive use of the social organizational affordances provided by directives to differentiate themselves in. interactions within their peer group. Griswold (2007) illustrated how six-to-eightyear-old Russian girls used directive forms (permission, information, and assistance requests), often produced in crouched bodily positions, to enact a subordinate position vis-à-vis a girl who peers constructed as occupying a leadership position in the group. They also requested that the girl in the leadership position, including 'mother,' make decisions about role assignments of other group members; the girl playing mother ratified this position through moves of her own. Kyratzis, Marx, and Wade (2001) observed four-year-old girls and boys project leadership roles in their respective peer groups by using assertive directive forms while receiving deferent forms - permission and information requests - from other group members. For example, one girl projected a leadership role by instructing other group members how to climb and by assuming the role of the oldest sister (' $\mathrm{I}^{\prime} \mathrm{m} 99^{\prime}$ ) in pretend play; the other girls made permission requests and information requests of this girl, deferrin in the interaction. 1 plished by one fivegame of news repor1 with discourse mar. our weather report transition points of tion by the other gr

In studying direc an ethnographic pe of an activity can cl ational features ( $d$ i Kyratzi, Marx, and for example, obser situations in a $\mathrm{Ma}$ organization was e dyad and other fea examining childre Spanish speakers $i$. taking roles, use towards younger maids'), modeled tion is evident in power code-switc inappropriate beh nied not only by registers negative

Several of the status relationshil (Andersen et al. 1 Ervin-Tripp, Guc Kernan and Kert positions of lead requests from ot] taken by a child studies consider struct asymmetri

\section{Play with I Participatio}

Another set of $\mathrm{rt}$ and identities ir (Rampton 2003, 
$\mathrm{n}$ orientation ol girls were sly able, conwas the baby

\section{ves}

ucting social membership btle observaso fully as in ildren realize 990: 127). (See ipp, Guo, and $\tan 1977$ ).

social identiay from adult shies at famildoing 'create lority, power, can American ocial relationig the role of hildren,' girls ig the role of immand them

of the social themselves in $v$ six-to-eightn, and assista subordinate ship position on, including abers; the girl ratzis, Marx, rship roles in ile receiving up members. other group $\left(\right.$ I'm $\left.^{\prime} 99^{\prime}\right)$ in tion requests of this girl, deferring to her superior knowledge and ratifying her dominant role in the interaction. Kyratzis (2007) demonstrated how asymmetry was accomplished by one five-year-old member of a friendship triad of preschool girls in a game of news reporter play. The girl enacting main reporter used in-role directives with discourse markers such as 'well,' 'so,' and 'now' (Now we return back to our weather report'). The projected right of this lead announcer to determine transition points of the activity was repeatedly ratified in the sequence of interaction by the other group members.

In studying directive-response sequences in pretend play and other exchanges, an ethnographic perspective permits us to examine how the social orchestration of an activity can change over time (Goodwin 2006: 155) as well as over other situational features (de León in press b; Evaldsson 2004; Kyratzis and Guo 2001; Kyratzi, Marx, and Wade 2001; Nakamura 2001). De León (in press a, in press b), for example, observing directive-response sequences among siblings in caregiving situations in a Mayan township in Chiapas, Mexico, found that siblings' social organization was emergent and varied, depending on the age composition of the dyad and other features of the 'sibling developmental niche.' Flores Nájera (2009), examining children's games (columpio or 'swing') among bilingual NahuatlSpanish speakers in Tlaxcala, Mexico, describes how older siblings, in their caretaking roles, use honorific forms to mitigate both directives and justifications towards younger siblings. In the pretend game of dueñas y criadas ('owners and maids'), modeled after urban Mexican culture, however, cross-situational variation is evident in how authority is displayed during play. Girls in positions of power code-switch from Nahuatl to Spanish to intensify negative evaluation of inappropriate behavior (exclusion of group members). Such actions are accompanied not only by response cries, grammatical intensifiers, and reduplication that registers negative assessment but also by glances displaying annoyance.

Several of the studies mentioned earlier documented children's sensitivity to status relationships in the adult world as seen in directive use during pretend play (Andersen et al. 1999; Aronsson and Thorell 1999; Corsaro 1985; Ervin-Tripp 1996; Ervin-Tripp, Guo, and Lampert 1990; Evaldsson and Tellgren 2009; MitchellKernan and Kernan 1977). The studies reviewed in this section document that positions of leadership are in addition constituted through the way in which requests from others are responded to, either ratifying or challenging the stance taken by a child proposing to act as leader in sequences of interaction. These studies consider how children use directives and other forms agentively to construct asymmetries in their own local social order.

\section{Play with Voicing, Stylization, Genre, and Participation Frameworks - Taking Stances}

Another set of resources that child peers can utilize in building their social worlds and identities includes the 'voicing' (Bakhtin 1981; Vološinov 1973), 'stylization' (Rampton 2003, 2006), and 'performance' (Bauman and Briggs 1990) of particular 
roles and speakers and the manipulation of participation frameworks during these stylized performances. Citing Goffman's work on frame analysis (Goffman 1974), Goodwin (1990: 230) argues that 'by telling a story a speaker is able to bring alive in the midst of ordinary conversation what is in essence a vernacular theatrical performance; the teller enacts the characters whose exploits are being recounted, and, with talk of a different type [...] comments on their meaning.' She notes Vološinov's (1973) point that 'a speaker never simply reports the talk of another but instead, in the very process of animating that talk, comments on it and shows his or her own alignment to it' (Goodwin 1990: 245). How the animator enacts the quoted speech of the author is critical for determining how others who view the performance align with the animator and evaluate the animated speaker.

\section{Animating and stylizing others in stories}

Children and teens are provided with a powerful means of disaligning from a speaker and their moral views when they animate that speaker and use his/her own words against them (Eder 1998; Goodwin 1990). When boys animate peergroup members as speaking in a high-pitched, cowardly fashion (Evaldsson 2002) or themselves as speaking assertively and challenging adult authority (Cheshire 2000), they index appropriate and inappropriate behavior for the peer group, projecting a value that boys should not act cowardly.

Teens 'use language and dialect in discursive practice to appropriate, explore, reproduce or challenge influential images and stereotypes of groups that they don't themselves (straightforwardly) belong to' (Rampton 1999: 421; emphasis in original). Rampton conducted 'micro-discursive analysis of particular episodes in which youngsters put on exaggerated posh and Cockney accents' (Rampton 2003: 76). These 14-year-olds, attending a multiethnic school serving low-income students in inner-city London, made use of these accents in 'stylised performances' (Rampton 2003: 67) to produce evaluative commentaries on others, frame comebacks to playful accusations, and achieve other effects in the local interaction. Rampton concluded that adolescents engage with, comment on, and 'denaturalize' cultural associations and stereotypes indexed by the accents and language varieties. Over time, such practices have the power to 'change the associative meaning potential of a particular language form or variety' (Rampton 2006: 343).

Studying interaction during focus groups, Keim (2008) observed a group of adolescent girls of Turkish heritage in Germany (i.e. the 'Turkish Powergirls') switching into playful performances and caricatures using features of dialects of various social groups that they did not consider themselves to belong to. For example, they used Gastarbeiterdeutsch ('migrant workers' German') to evoke 'the negative social category of the "backward Turk"'(Keim 2008: 219). However, they also used Gastarbeiterdeutsch to evoke the German monolingual speaker's 'stereotypes about migrants and force him/her interactively to cope with these stereotypes' (Keim 2008: 219) in the moment. The ways in which children and teens style, stylize, and animate others in play, disputes, and stories allow them to

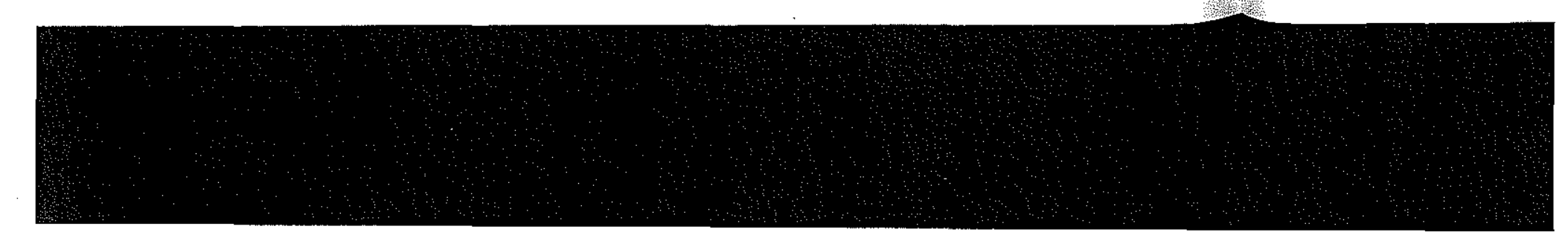


during these Iffman 1974), o bring alive lar theatrical g recounted, y.' She notes $k$ of another it and shows or enacts the tho view the aker.

ning from a use his/her limate peerIdsson 2002) ty (Cheshire peer group, ate, explore, os that they 1; emphasis lar episodes s' (Rampton low-income ed performthers, frame . 1 the local ient on, and accents and tge the asso' (Rampton

a group of ?owergirls') $f$ dialects of ong to. For s evoke 'the wever, they ker's 'sterethese stere$x$ and teens iw them to render social commentary and construct local social and moral order in peergroup interactions.

\section{Play with register, genre, and participation frameworks: Making social commentary}

In pretend play, children play with register and genre and playfully perform, combine, delete, and juxtapose features from different registers/genres (Minks 2006, 2010; Reynolds 2002, 2008, 2010). These playful exploratory combinations provide children with a resource for exploring relations among different social roles, settings, and discourses (Briggs and Bauman 1992); for delivering powerful moral messages, and for negotiating and subverting existing social order (de León 2007; Kyratzis 2007; Loyd 2006, 2011; Minks 2006; Paugh 2005; Reynolds 2002, $2007,2008,2010)$. Even children in the early childhood years show agency in using such resources. For example, Reynolds (2007) examined how two-to-fourteenyear-old children from an extended kin network group in a highland Guatemala Kaqchikel Maya town 'entextualized' (Bauman and Briggs 1990) a formulaic politeness routine, the greeting Buenos dias, combined it with another genre of respect, a military salute, and utilized it to negotiate the local social order of kin group exchanges. By extending use of the genre to contexts other than that in which it canonically occurs, as 'a respectful greeting routine' (Reynolds 2007: 447), and by mockingly tying it to the format of and elaborating (with insult terms) other group members' uses of the greeting, the children subverted existing hierarchical relations among members of the kin group, conveyed disrespect, and negotiated local social order.

Age hierarchies were also observed to be subverted by children in an ethnographic study conducted by de León (2007) in Zinacantan, Chiapas, Mexico. She observed a pair of young Tzotzil Mayan siblings, a two-year-old and a four-yearold, embedding a politeness routine, an invitation to eat ('Do you want to eat?'), in inappropriate contexts. The invitation or call is usually uttered by children with an evidential (i.e. 'do you want to eat, it is said') when they are calling other children in to eat for an adult, acting as the adult's messenger. The evidential indexes their role as 'animators' (Goffman 1974) of an adult-authored message. However, the children subverted the form, leaving off the evidential. They uttered it in the presence of their grandfather and format-tied to his posings of the invitation/ question to them, thereby subverting existing age hierarchies.

In another analysis, Reynolds (2010) examined how two children, a six-year-old and an 11-year-old, enacted el Desafio ('the Challenge') performances that they had observed being performed in the streets of their Kaqchikel Maya town. This is a Spanish reconquest genre that pits el Rey Cristiano (the Christian king) against el Rey Moro (the Moorish king). The children combined poetic forms from this genre with forms that indexed a caretaking register. Reynolds argued that, by so doing, the children were able to draw an analogy between varieties of authority encompassed in the two kinds of roles, thereby providing them with a resource for exploring and subverting their own unequal social positions within the sibling-kin 
group. Tetreault (2009) observed teenagers of Algerian descent in France playfully appropriating and 'entextualizing' French television host register, thereby 'capitaliz[ing] on the primary power of television hosts: to contextualize guests within interactions that the host primarily orchestrates' (Tetreault 2009: 205). The peers exploited and arranged participant frameworks, enabling them to 'create a generalized footing that facilitates embedded rumors about their tutors and peer[s]' (Tetreault 2009: 217). The ironic footing also facilitated embedded commentary on the broader French society where they lived. Kyratzis (2007) observed members of a peer group of American preschool children exploiting features of announcer/ news reporter register to bring on, present, and remove other characters (e.g. guest announcers) from the stage, to build local social order among group members.

Poveda and Marcos (2005) documented Gitano children (i.e. children living in Romany or Gypsy communities) teasing and animating non-Gitano children living in the same public housing project in a community in Spain during a stone fight. The Gitano children were observed animating the non-Gitano children as saying things ('I am a baby') that indexed what were, from the perspective of the children's cultural worlds (Corsaro 1997), child-based ideologies regarding age; that is, 'social categories that are problematic (face threatening) for [...] recipient $[s]^{\prime}$ (Poveda and Marcos 2005: 344). By drawing on their own child-based cultural ideologies and resources, the children were able to 'transform and reinterpret sociogeographical arrangements that have been put into place primarily by adults' (Poveda and Marcos 2005: 346).

Even young toddlers have been observed appropriating formulaic expressions from adult caregivers and embedding them in new contexts for rhetorical effect. Köymen (2008, 2010; Köymen and Kyratzis 2009) observed 24-30-month-old children appropriating the expressions of caregivers ('T don't like it when you ...'), provided to children as part of an institutional, curriculum-based mandate to 'use your words' and make their affective states known to peers in negotiating conflicts. The children embedded and 'recontextualized' (Ochs 1996) these formulaic utterances in new contexts that were not the idealized uses of the expressions. In one example, a child used the formula to provoke a conflict with a peer rather than to resolve one, thereby perpetuating conflict and subverting the adult intention of the practice. In an ethnographic study conducted in Nicastro, southern Italy, Loyd (2006) observed children, including a three-year-old, appropriating adult-like expressions and enacting 'adult personas' in their conflicts with peers. These shifts in footing enabled children to project moral authority and influence local social order during the disputes. In another study, Reynolds (2008) examined how young children in a Kaqchikel Maya town countered attempts by older members of the sibling/kin group to author words for them during teasing routines. The authored words were intended to put down other, older members of the sibling-kin group. By 'choosing sides and authoring their own words' (Reynolds 2008: 96), the children were able to take their own stances and subvert local age hierarchies.

Howard (2009), observing a peer group of Thai boys, noted how the youngest, a five-year-old, created a space for himself to participate by appropriating a game

role and game game; through answering the $r$ by an older boy. Miskitu childret 'genres such as of subversive $\mathrm{re}$ 118). In so doin unsanctioned fo unsanctioned be vided with a ve multicultural ex Through varied enact, stylize, a making 'artful t by embedding $r$ exploiting partic and evaluate $\mathrm{sc}$ hierarchies, and

\section{Juxtaposin}

A considerable a 'contextualiza tions, serving to social and situc 1998; Ervin-Tri switching can b or kind of talk Zentella 1997); i Tang, and Köyr Code-switching petitive orienta an interactiona (Cromdal 2004: episodes of 'po

Researchers of language cor and reproduce of the two lang Garrett and Ba Paugh 2005, t code-switching selection of $\mathrm{cc}$ 
France playfully egister, thereby extualize guests t 2009: 205). The hem to 'create a heir tutors and edded commenserved members 3 of announcer/ ucters (e.g. guest members. lildren living in Jitano children I during a stone mno children as rspective of the regarding age; ...] recipient[s]' -based cultural and reinterpret arily by adults'

aic expressions retorical effect. nonth-old chilvhen you ...'), randate to 'use zgotiating conhese formulaic expressions. In 1 a peer rather he adult intenstro, southern appropriating ts with peers. and influence 08) examined ipts by older teasing roumembers of own words' and subvert ting a game role and game speech that were more typical of expert participants in a riddle game; through manipulating the game-embedded participation framework (by answering the riddle rather than repeating the question he was prompted to ask by an older boy), he subverted local age hierarchies. Minks observed Nicaraguan Miskitu children living on Corn Island engaging in pretend play by juxtaposing 'genres such as recitation, note-taking, testing, teacher talk, and a particular kind of subversive reading and writing called "copying" or "cheating" (Minks 2006: 118). In so doing the children were able to render commentary on peers, 'act out unsanctioned forms of behavior,' and explore and challenge the limits of such unsanctioned behavior among themselves (Minks 2006: 123). They were also provided with a venue to draw links between different 'bodies of discourse' in their multicultural experience (Minks 2006: 122; see also Bauman and Briggs 1990). Through varied means, children animate, entextualize (Bauman and Briggs 1990), enact, stylize, and 'recontextualize' (Ochs 1992) the expressions of others. By making 'artful use of speech in expressive performance' (Rampton 2006: 16) and by embedding register and genre elements agentively in new contexts, as well as exploiting participation frameworks in interaction with peers and kin, they explore and evaluate social relations in the adult world, challenge and subvert existing hierarchies, and negotiate their places in the local social order.

\section{Juxtaposing Resources from Multiple Languages}

A considerable body of research has examined how code-switching functions as a 'contextualization cue' (Gumperz 1982) during children's peer-group conversations, serving to 'alert participants in the course of the ongoing interaction to the social and situational context of the conversation' ( $\mathrm{Li}$ 1998: 164; see also Auer 1998; Ervin-Tripp and Reyes 2005; Gumperz and Cook-Gumperz 2005). Codeswitching can be used to negotiate shifts in alignment, 'footing' (Goffman 1979), or kind of talk (Ervin-Tripp and Reyes 2005; Gumperz and Cook-Gumperz 2005; Zentella 1997); in 'participation framework' (Cromdal and Aronsson 2000; Kyratzis, Tang, and Köymen 2009); or 'production format' (Cromdal and Aronsson 2000). Code-switching can serve as a resource for displaying speakers' shifting or competitive orientation to an exchange and for resolving overlap (Cromdal 2001), as an 'interactional resource in the sequential construction of oppositional stances' (Cromdal 2004: 53), and for disaligning with others' talk and suggestions during episodes of 'power-wielding' (Jorgensen 1998).

Researchers taking a language socialization perspective examine how, in areas of language contact, through their language practices in play, children 'draw on. and reproduce more broadly held ideologies about the relationship and meanings of the two languages' (Schieffelin 2003: 158). (See also Garrett 2005, this volume; Garrett and Baquedano-López 2002; Kyratzis, Reynolds, and Evaldsson 2010; Paugh 2005, this volume; Zentella 1997). Paugh (2005) followed children's code-switching and play practices in peer/kin groups in Dominica. Through their selection of codes to enact particular adult roles in role-play, the children, 
including three-year-olds, could 'transform the associations with the languages through using them in their play' (Paugh 2005: 80), which in certain ways could contribute to the maintenance of Patwa in the region. Minks found Miskitu children on Corn Island moving very 'easily across social and linguistic boundaries' (2006: 125) in peer-group interactions. With such practices, children 'socialize heteroglossia' within the peer group (Minks 2010), possibly supporting the maintenance of indigenous languages such as Miskitu in areas undergoing language shift.

However, children's peer- and sibling/kin-group practices can also contribute to language shift and language loss in a community. Quichua-Spanish-speaking children in a highland Ecuadorian community did not play together in Quichua, preferring Spanish, despite Quichua being used among adults in the community (Rindstedt and Aronsson 2002). In immigrant communities, practices within children's peer groups can also reproduce or challenge dominant societal discourses (Garrett and Baquedano-López 2002; see also Baquedano-López and Mangual Figueroa, this volume; García-Sánchez, this volume). Cekaite and Evaldsson (2008) and Evaldsson and Cekaite (2010) followed multiethnic peer groups in two schools in Sweden, examining how group members reproduced monolingual norms of the school by criticizing their peers for uses of languages other than Swedish. At alternative moments, however, the children challenged these same norms through using code-switching and crossing, indexing bilingual identities, and defying monolingual institutional norms. García-Sánchez (2010) observed how members of a peer group of immigrant Moroccan girls in Spain made use of bilingual practices, using both Moroccan Arabic and Spanish during pretend play with their dolls. In the bilingual community in which they were growing up, bilingual play provided a space in which group members explored conflicting forms of gender identification. Garrett (2007) observed older St. Lucian boys to use Kwéyòl in 'unsupervised peer contexts,' in contrast to most everyday, adultsupervised contexts, in which they used English. Garrett concluded that Kwéyòl was used by these boys to 'index adult masculinity' and work out their own domain associations and 'subjectivities' for English and Kwéyòl (Garrett 2007: 249). Kyratzis (2010) observed members of a peer group of Mexican-heritage immigrant girls in a bilingual preschool classroom in California. Through codeswitching, the children negotiated shifting activity frames, inscribed domain associations for their two languages (Garrett 2005; Paugh 2005; Schieffelin 2003), and challenged institutionally inscribed discourses. A peer group of New York Puerto Rican children (Zentella 1997) and a peer group of Dominican American youths in Providence, Rhode Island (Bailey 2007) used code-switching and 'heteroglossic' language practices (Bakhtin 1981) to effect changes in the local interactive context in group interactions, simultaneously challenging language ideologies of the dominant US society. Through their language practices within the peer group, children challenge, 'draw on, and reproduce more broadly held language ideologies' (Schieffelin 2003: 158) of the multilingual communities in which they grow up, as they act to accomplish their local social organization.

\section{Conclusion}

Kulick and Schieffe lations of habitus language are accou thus, 'processes of asserted more thar 351-2). This chapt peer-based social $c$ cultures and phys within their own $F$ ate behavior for 1 Schieffelin and $\mathrm{OC}$ research 'has been is universal abor (Schieffelin and C same- and near-a६ rated areas of chi socialize one ano

Like previous of one another $(\mathrm{E}$ Cook-Gumperz a Mitchell-Kernan reviews (Cook-G 2004), the studie resources' (Gask worlds, ones tha this body of stud emphasis to (1) $\mathrm{c}$ social organizati ied, and situater using ethnograf by children in expand the type ings in which o press b; Minks: world's childret studies expand in multicultura conducted in [ Mexico, Nicara communities. ] ences across $\mathrm{CC}$ 
$\mathrm{I}$ the languages ain ways could Id Miskitu chilitic boundaries' ldren 'socialize rtting the mainjoing language

also contribute anish-speaking .er in Quichua, the community ces within chilietal discourses $:$ and Mangual and Evaldsson $r$ groups in two d monolingual iges other than yed these same gual identities, 2010) observed in made use of ig pretend play e growing up, red conflicting Lucian boys to veryday, adulted that Kwéyòl out their own (Garrett 2007: exican-heritage Through coded domain assofelin 2003), and aw York Puerto nerican youths l 'heteroglossic' ractive context ,ies of the domzroup, children age ideologies' ey grow up, as

\section{Conclusion}

Kulick and Schieffelin have recently argued that missing from Bourdieu's formulations of habitus and Judith Butler's claims about the performative power of language are accounts of 'how' it is that individuals are socialized into a habitus; thus, 'processes of becoming a culturally intelligible subject are assumed and asserted more than they are actually demonstrated' (Kulick and Schieffelin 2004: 351-2). This chapter has documented embodied language practices entailed in peer-based social control and negotiation that children - across an array of diverse cultures and physical locales - make use of to build local social organization within their own peer-group communities and index appropriate and inappropriate behavior for the local peer group through (universal) language practices. Schieffelin and Ochs have argued that an important goal of language socialization research 'has been to articulate a model that reconciles what is particular and what is universal about the communicative practices of novices and of experts' (Schieffelin and Ochs 1996: 257). We have demonstrated that, within their own same- and near-age group communities, in neighborhoods, schoolyards, and separated areas of children's interaction, away from the influence of adults, children socialize one another.

Like previous bodies of research on children's peer cultures and socialization of one another (Blum-Kulka and Snow 2004; Cook-Gumperz and Kyratzis 2001; Cook-Gumperz and Corsaro 1986; Corsaro 1985, 1997; Eder 1995; Ervin-Tripp and Mitchell-Kernan 1977; Gaskins, Miller, and Corsaro 1992) and as discussed in prior reviews (Cook-Gumperz and Kyratzis 2001; Goodwin and Kyratzis 2007; Kyratzis 2004), the studies reviewed here focus on how children 'creatively use cultural resources' (Gaskins, Miller, and Corsaro 1992: 7) in building their own social worlds, ones that can be very different from the life worlds of adults. However, this body of studies differs from other peer socialization research in giving special emphasis to (1) children's agency in attending to and building local hierarchy and social organization; (2) the importance of examining moment-to-moment, embodied, and situated practices in sequences of interaction; and (3) the relevance of using ethnography to provide broader perspectives on the resources drawn upon by children in moment-to-moment interactions. Importantly, the studies also expand the types of children's peer groups studied to include age-graded groupings in which older siblings and kin care for younger children. (de León. 2007, in press b; Minks 2010; Reynolds 2007, 2010; Rogoff 1981). Moreover, as many of the world's children currently grow up in postcolonial and transnational societies, the studies expand the types of children's peer groups to include peer and kin groups in multicultural and multilingual communities. The research reported on was conducted in Denmark, Dominica, England, France, Germany, Guatemala, Italy, Mexico, Nicaragua, Spain, St. Lucia, Sweden, Thailand, Turkey, and diverse US communities. The comparative perspective taken in this review revealed differences across communities and cultures in practices and ideologies that children. 
could draw upon. For example, children freely invoked differing cultural images and ideologies of gender, age-based, or language groups that were salient in their communities. They did so by using various indexical signs (Ochs 1996). These included members' category terms - such as 'girl' and 'boy' (Goodwin 2011), 'Gypsy' versus 'Romany' (Evaldsson 2005) - as well as practices such as parental name-calling, as used among French adolescents of Algerian descent (Tetreault 2010). These terms and practices were freely invoked and challenged by children for their own purposes. However, the studies also revealed universals, such as the agency shown by children in utilizing these cultural resources towards constituting their local social order, as well as the potential importance of these children's group practices for the larger communities' cultural reproduction and change.

Many of the studies reviewed here examine how children utilize a variety of resources to build, manage, and monitor local hierarchies. These include selecting and enacting pretend roles privileged to speak with high- (and low-) status control act forms (Kyratzis 2007), and utilizing positionings of the body (Griswold 2007) as well as forms of sanctioning and exclusion (Evaldsson and Tellgren 2009; Goodwin 2006). A central finding was that positions of power and subordination emerge and unfold in sequences of interaction. A child who projects a position of control over the actions of others in the group through directives and positioning of the body, or who projects another child as being in control, must have that position ratified by other group members in sequences of interaction. The studies document that hierarchy, rather than being a byproduct of the age make-up of the group, is emergent and interactionally achieved. Hierarchy is negotiated in the moment, and a child who is constructed as a lower-status member in one context can challenge that status in another through their language practices in the peer or kin group, as seen in many of the studies reviewed here (e.g. de León in press b; Goodwin 2006; Griswold 2007; Howard 2009, this volume; Kyratzis, Marx, and Wade 2001; Reynolds 2010). As noted by Bucholtz (2007), power is also indexed by discernment; therefore, forms of assessment (e.g. gossip, ritual insult, and portrayals of others in compliments, games, and stories) become primary resources through which children build their social worlds. Children were observed to be continually defining and redefining the moral order through assessment and evaluation and to hold others accountable to the important social categories of the group.

Although the studies reviewed here were concerned with how participants constituted their social and moral order through publicly available resources in sequences of interaction during talk-in-interaction, an ethnographic perspective was also needed to understand children's categorizations and assessments. An ethnographic perspective reveals the 'wider social structures and discourses' (Evaldsson 2005: 764) that are available in the broader community of which the peer group is a part and also how the children agentively draw on, reproduce, and resist those ideologies available to them (Ochs 1996; Schieffelin 2003). The studies therefore show how children (even quite young children), not only adults, can be agents of cultural reproduction and change, thereby expanding the language socialization paradigm.
Several of the st not only in evoking tion but in doing : negative (and posi in which they live, through approprii Enactments in the stances and to ex] allowing them to egorizations of $\mathrm{pi}$ 1961: 96) of story common or diver local social order. roles and places 2005; Schieffelin Evaldsson 2008; I ated action with

In summary, $t$ entailed in childof diverse culture 'arenas of action' able for the socii graphic example forms of moral a forms) are const tive practices wi

\section{REFERENCE}

Andersen, E. S., I and Gonnerma linguistic evide acquisition of $c$ register variab. 31(10): 1339-51

Andersen, E. S. ( The Sociolingui London: Rout] Antaki, C. (1994 The Social Org London: Bant

Antaki, C. and I Identity as an In C. Antaki 
ring cultural images were salient in their (Ochs 1996). These 'y' (Goodwin 2011), ices such as parental $\mathrm{n}$ descent (Tetreault allenged by children uiversals, such as the is towards constitut'e of these children's ction and change. i utilize a variety of ese include selecting l low-) status control Jdy (Griswold 2007) and Tellgren 2009; r and subordination rojects a position of ives and positioning trol, must have that raction. The studies sage make-up of the is negotiated in the mber in one context practices in the peer ə.g. de León in press Kyratzis, Marx, and wer is also indexed ?, ritual insult, and re primary resources were observed to be igh assessment and cial categories of the

th how participants railable resources in graphic perspective nd assessments. An res and discourses' aunity of which the raw on, reproduce, hieffelin 2003). The en), not only adults, expanding the lan-

Several of the studies reviewed underscore the ingenuity of teens and children, not only in evoking negative characteristics of peers and others in situated interaction but in doing so through indirect, veiled, and humorous means. They index negative (and positive) social categories of their peers or tutors, or of the societies in which they live, through exploiting footings and participation frameworks and through appropriating others' words in pretend games, disputes, and stories. Enactments in the frame of play allow children to assume authoritative roles and stances and to explore relations among different voices of authority, sometimes allowing them to subvert those same relations. Through the evaluations and categorizations of person that they make in different situated activities (Goffman 1961: 96) of storytelling, ritual insult, and pretend play, children take up either common or divergent stances towards the target, building social alignments and local social order. In multilingual settings, children also show agency in assigning roles and places to their two (or more) languages in their talk and play (Paugh 2005; Schieffelin 2003) and in drawing on dominant discourses (Cekaite and Evaldsson 2008; Evaldsson 2005; Kyratzis, Reynolds, and Evaldsson 2010) in situated action with their peers.

In summary, the studies reviewed in this chapter examine linguistic practices entailed in child-based social control and negotiation that children across an array of diverse cultures make use of to build local social organization within their own 'arenas of action' (Hutchby and Moran-Ellis 1998) and hold one another accountable for the social activity in progress. The work reviewed here provides ethnographic examples of empirically grounded studies of how local identities and forms of moral and social order (which through time evolve into more enduring forms) are constituted by children as the product of moment-to-moment interactive practices within their peer and sibling/kin groups.

\section{REFERENCES}

Andersen, E. S., Brizuela, M., Dupuy, B., and Gonnerman, L. (1999) Crosslinguistic evidence for the early acquisition of discourse markers as register variables. Journal of Pragmatics 31(10): 1339-51.

Andersen, E. S. (1990) Speaking with Style: The Sociolinguistic Skills of Children. London: Routledge.

Antaki, C. (1994) Explaining and Arguing: The Social Organization of Accounts. London: Bantam.

Antaki, C. and Widdicombe, S. (1998) Identity as an achievement and as a tool. In C. Antaki and S. Widdicombe (eds.), Identities in Talk. 1-14. London: Sage.

Aronsson, K. and Thorell, M. (1999) Family politics in children's play directives. fournal of Pragmatics 31: 25-48.

Auer, P. (1998) Introduction: Bilingual conversation revisited. In P. Auer (ed.), Code-Switching in Conversation: Language, Interaction, and Identity. 1-24. London: Routledge.

Bailey, B. (2007) Heteroglossia and boundaries. In M. Heller (ed.), Bilingualism: A Social Approach. 257-74. New York: Palgrave Macmillan. 
Bakhtin, M. (1981) M. Holquist (ed.), The Dialogic Imagination: Four Essays. Austin, TX: University of Texas Press.

Bauman, R. and Briggs, C. L. (1990) Poetics and performance as critical perspectives on language and social life. Annual Review of Anthropology 19: 59-88.

Berentzen, S. (1984) Children constructing their social world: An analysis of gender contrast in children's interaction in a nursery school. Bergen Occasional Papers in Social Anthropology, No. 36. Bergen, Norway: University of Bergen.

Blum-Kulka, S. and Snow, C. E. (2004) Introduction: The potential of peer talk. Discourse Studies 6(3): 291-306.

Bourdieu, P. (1984) Distinction: A Social Critique of the Judgment of Taste. Cambridge, MA: Harvard University Press.

Briggs, C. L. and Bauman, R. (1992) Genre, intertextuality, and social power. Joumal of Linguistic Anthropology 2: 131-72.

Bucholtz, M. (1999) 'Why be normal?': Language and identity practices in a community of nerd girls. Language in Society 28: 203-23.

Bucholtz, M. (2002) Youth and cultural practice. Annual Review in Anthropology 31: 525-52.

Bucholtz, M. (2007) Word up: Social meanings of slang in California youth culture. In L. Monaghan and J. E. Goodman (eds.), A Cultural Approach to Interpersonal Communication: Essential Readings. 243-67. Malden, MA: Blackwell Publishing.

Bucholtz, M. (2011) White Kids: Language, Race, and Styles of Youth Identity. Cambridge: Cambridge University Press.

Burdelski, M. (2010) Socializing politeness routines: Multimodality and social action in a Japanese preschool. Journal of Pragmatics 42: 1606-21.

Butler, C. and Weatherall, A. (2006) 'No, we're not playing families': Membership categorization in children's play. Research on Language and Social Interaction 39(4): $441-70$.
Cekaite, A. and Evaldsson, A.-C. (2008)

Staging linguistic identities and negotiating monolingual norms in multiethnic school settings. International Joumal of Multilingualism 5: 177-96.

Cheshire, J. (2000) The telling or the tale? Narratives and gender in adolescent friendship networks. Journal of Sociolinguistics 4(2): 234-62.

Clancy, P. M. (1986) The acquisition of communicative style in Japanese. In B. B. Schieffelin and E. Ochs (eds.), Language Socialization across Cultures. 213-50. Cambridge: Cambridge University Press.

Cook-Gumperz, J. and Kyratzis, A. (2001) Child discourse. In D. Schiffrin, D. Tannen, and $\mathrm{H}$. Hamilton (eds.), The Handbook of Discourse Analysis. 590-611. Oxford: Blackwell.

Cook-Gumperz, J. and Corsaro, W. (1986) Introduction. In J. Cook-Gumperz, W. A. Corsaro, and J. Streeck (eds.), Children's Worlds and Children's Language. 1-11. Berlin: Mouton de Gruyter.

Corsaro, W. A. (1985) Friendship and Peer Culture in the Early Years. Norwood NJ: Ablex.

Corsaro, W. A. (1997) The Sociology of Childhood. Thousand Oaks, CA: Pine Forge Press.

Cromdal, J. (2004) Building bilingual oppositions: Code-switching in children's disputes. Language in Society 33: 33-58.

Cromdal, J. (2001) Overlap in bilingual play: Some implications of codeswitching for overlap resolution. Research on Language and Social Interaction 34(4): 421-51.

Cromdal, J, and Aronsson, K. (2000) Footing in bilingual play. Journal of Sociolinguistics 4(3): 435-57.

Danby, S. and Baker, C. (1998) How to be masculine in the block area. Childhood 5(2): 151-75.

de León, L. (2007) Parallelism, metalinguistic play, and the interactive emergence of Zinacantec Mayan siblings' culture. Research on
Language and Sociai 405-36.

de León, L. (in press atención: Directivc responsabilidad er de los Niños May: Zavala and S. Fris. Aprendizaje, Cultur Peru: Fondo Edito Católica Pontificia de León, L. (in press coming!' Triadic $\mathrm{d}$ in socialization of Children. In A. Br (eds.). Proceedings and Maya Conferer 21.

Du Bois, J. W. (2007 R. Englebretson 4 Subjectivity in Intt Amsterdam, The Benjamins.

Eckert, P. (1987) Joc. Categories and Ide New York: Teach

Eckert, P. (2003) La adolescence. In $\mathrm{J}$ Meyerhoff (eds.) Language and $\mathrm{Ges}$ MA: Blackwell.

Eckert, P. and $\mathrm{McC}$ Think practicall Language and g. based practice. Anthropology, 21

Eder, D. (1995) Sch Adolescent Cultu Rutgers Univer

Eder, D. (1998) De culture through In S. M. Hoyle Kids Talk: Strates Childhood. 82-94 University Pres

Ervin-Tripp, S. M. language. In D. Kyratzis, and J. Interaction, Soci Essays in Honor 
son, A.-C. (2008)

nntities and gual norms in sttings. International tism 5: 177-96. telling or the tale? er in adolescent Journal of 34-62. a acquisition of in Japanese. In E. Ochs (eds.), across Cultures. Jambridge

Kyratzis, A. (2001) - Schiffrin, D. itton (eds.), The Analysis. 590-611.

Zorsaro, W. (1986) ok-Gumperz, W. A. k (eds.), Children's sanguage. 1-11. uyter. iendship and Peer ars. Norwood NJ:

e Sociology of Jaks, CA: Pine

Ig bilingual ching in children's sciety 33: 33-58. ap in bilingual is of coderesolution. nd Social Interaction

n, K. (2000) ay. Journal of j-57.

1998) How to be area. Childhood

lism, $d$ the interactive ec Mayan ch on
Language and Social Interaction 40(4): 405-36.

de León, L. (in press a) 'Calibrando' la atención: Directivos, adiestramiento, y responsabilidad en el trabajo doméstico de los Niños Mayas Zinacantecos. In V. Zavala and S. Frisancho (eds.), Aprendizaje, Cultura y Desarrollo. Lima, Peru: Fondo Editorial de la Universidad Católica Pontificia.

de León, L. (in press b) 'The J'lk' $a$ l is coming!' Triadic directives and emotion in socialization of Zinacantec Mayan Children. In A. Breton and P. Nondedeo (eds.). Proceedings of the 13th European and Maya Conference. Acta Mesoamericana 21.

Du Bois, J. W. (2007) The stance triangle. In R. Englebretson (ed.), Stance in Discourse: Subjectivity in Interaction. 13-182. Amsterdam, The Netherlands: Benjamins.

Eckert, P. (1987) Jocks and Burnouts: Social Categories and Identity in the High School. New York: Teachers College Press.

Eckert, P. (2003) Language and gender in adolescence. In J. Holmes and $\mathrm{M}$. Meyerhoff (eds.), The Handbook of Language and Gender. 381-400. Malden, MA: Blackwell.

Eckert, P. and McConnell-Ginet, S. (1992) Think practically and look locally: Language and gender as communitybased practice. Annual Review of Anthropology, 21: 461-90.

Eder, D. (1995) School Talk: Gender and Adolescent Culture. New Brunswick, NJ: Rutgers University Press.

Eder, D. (1998) Developing adolescent peer culture through collaborative narration. In S. M. Hoyle and C. T. Adger (eds.), Kids Talk: Strategic Language Use in Later Childhood. 82-94. Oxford: Oxford University Press.

Ervin-Tripp, S. M. (1996) Context in language. In D. I. Slobin, J. Gerhardt, A. Kyratzis, and J. Guo (eds.), Social Interaction, Social Context, and Language: Essays in Honor of Susan Eroin-Tripp.
21-36. Mahwah, NJ: Lawrence Erlbaum.

Ervin-Tripp, S. M., Guo, J., and Lampert, M. D. (1990) Politeness and persuasion in children's control acts. Journal of Pragmatics 14(2): 307-31.

Ervin-Tripp, S. M. and Reyes, I. (2005) Child code-switching and adult content contrasts. International Journal of Bilingualism 9(1): 85-102.

Ervin-Tripp, S. and Mitchell-Kernan, C. (1977) Introduction. In S. Ervin-Tripp and C. Mitchell-Kernan (eds.), Child Discourse. 1-26. New York: Academic Press.

Evaldsson, A.-C. (2002) Boys' gossip telling: Staging identities and indexing (unacceptable) masculine behavior. Text 22(2): 199-225.

Evaldsson, A.-C. (2004) Shifting moral stances: Morality and gender in samesex and cross-sex game interaction. The situational relevance of rules in same sex and cross sex games. Research on Language and Social Interaction 37.(3): 331-63.

Evaldsson, A.-C. (2005) Staging insults and mobilizing categorizations in a multiethnic peer group. Discourse $\mathcal{E}$ Society 16(6): 763-86.

Evaldsson, A.-C. (2007) Accounting for friendship: Moral ordering and category membership in preadolescent girls ${ }^{\prime}$ relational talk. Research on Language and Social Interaction 40(4): 377-404.

Evaldson, A.-C. and Cekaite, A. (2010) Subverting and reproducing institutionalized norms for language use in multilingual peer groups. Pragmatics 20(4): 587-605.

Evaldsson, A.-C. and Tellgren, B. (2009) 'Don't enter - it's dangerous':

Negotiations for power and exclusion in preschool girls' play interactions. Educational and Child Psychology 26(2): 9-18.

Flores Nájera, L. (2009) Los Directivos en la Organización Social del Grupo de Pares de Niños Bilingües de San Isidro Buensuceso, 
Tlaxcala: Un Enfoque Interactivo, Maestria en Lingüística Indoamericana. Mexico City, Mexico: CIESAS.

García-Sánchez, I. (2010) Serious games: Code-switching and gendered identities in Moroccan immigrant girls' pretend play. Pragmatics 20(4): 523-55.

Garrett, P. B. (2005) What a language is good for: Language socialization, language shift, and the persistence of code-specific genres in St. Lucia. Language in Society 34(3): 327-61.

Garrett, P. B. (2007) Language socialization and (re)production of bilingual subjectivities. In M. Heller (ed.), Bilingualism: A Social Approach. 233-56. New York: Palgrave Macmillan.

Garrett, P. B. and Baquedano-López, P. (2002) Language socialization: Reproduction and continuity, transformation and change. Annual Review of Anthropology 31: 339-61.

Gaskins, S., Miller, P. J., and Corsaro, W. A. (1992) Theoretical and methodological perspectives in the interpretive study of children. In W. A. Corsaro and P. J. Miller (eds.), Interpretive Approaches to Children's Socialization. 5-24. San Francisco, CA: Jossey-Bass.

Goffman, E. (1961) Encounters: Two Studies in the Sociology of Interaction. Indianapolis, IN: Bobbs-Merrill.

Goffman, E. (1967) Interaction Ritual: Essays in Face to Face Behavior. Garden City, NY: Doubleday.

Goffman, E. (1974) Frame Analysis: An Essay on the Organization of Experience. New York: Harper and Row.

Goffman, E. (1979) Footing. Semiotica 25: 1-29.

Goldman, L. R. (1998) Child's Play: Myth, Mimesis, and Make-Believe. Oxford: Berg.

Goodenough, W. H. (1965) Rethinking 'status' and 'role': Toward a general model of the cultural organization of social relationships. In M. Banton (ed.), The Relevance of Models for Social Anthropology. 1-24. London: Tavistock.
Goodenough, W. H. (1981) Culture, Language and Society. Menlo Park, CA: The Benjamin/Cummings Publishing Company.

Goodwin, C. and Goodwin, M. H. (1987)

Concurrent operations on talk: Notes on the interactive organization of assessments. IPrA Papers in Pragmatics 1(1): $1-52$

Goodwin, M. H. (1990) He-Said-She-Said: Talk as Social Organization Among Black Children. Bloomington, IN: Indiana University Press.

Goodwin, M. H. (1993) Accomplishing social organization in girls' play: Patterns of competition and cooperation in an African-American working-class girls' group. In S. T. Hollis, L. Pershing, and M. J. Young (eds.), Feminist Theory and the Study of Folklore. 149-65. Urbana, IL: University of Illinois Press.

Goodwin, M. H. (2006) The Hidden Life of Girls: Games of Stance, Status, and Exclusion. Oxford: Blackwell.

Goodwin, M. H. (2007) Participation and embodied action in preadolescent girls' assessment activity. Research on Language and Social Interaction 40(4): 353-76.

Goodwin, M. H. (2008) The embodiment of friendship, power, and marginalization in girls' interactions. Girlhood Studies: An Interdisciplinary Journal 1(2): 72-94.

Goodwin, M. H. (2011) Engendering children's talk. In E. H. Stokoe and S. A. Speer (eds.), Conversation and Gender. 251-71. Cambridge: Cambridge University Press.

Goodwin, M. H. and Alim, H. S. (2010) 'Whatever (neck roll, teeth suck, eyeball roll)': Transmodal stylization and stance display in preadolescent girls argumentative talk. Journal of Linguistic Anthropology. 20(1): 179-94.

Goodwin, M. H. and Kyratzis, A. (2007) Children socializing children: Practices for negotiating the social order among peers. Research on Language and Social Interaction 40(4): 279-89.
Griswold, O. (2007) Ar Discursive practices pretend play. Resear Social Interaction 40(

Gumperz, J. J. (1982) I Cambridge: Cambri

Gumperz, J. J. and Cc (2005) Making spac communicative pra Pragmatics 2(1): 1-2

Henderson, J. (2009) ] Anticipatory Social Virtual World. Mas University of Calife

Howard, K. M. (2009 spinning out: Repe decalibration in Th: genres. Language ir 339-63.

Hoyle, S. M. (1998) F role play. In S. M. (eds.), Kids Talk: St Later Childhood. 47. University Press.

Hutchby, I. and Mor Introduction. In I. Moran-Ellis (eds.) Competence: Arena London: Falmer F

Jaffe, A. (2009) Intro sociolinguistics of (ed.), Stance: Socic 3-28. Oxford: Oxt

Jorgensen, J. N. (19: acquisition of $\mathrm{coc}$ power-wielding. Code-Switching in Interaction, and Id Routledge.

Keim, I. (2008) Lin communication, identity: Case st group in Mannh Lytra and J. N. J Multilingualism Contexts: Cross- on Turkish-Speaki Copenhagen Stud 45. 178-226. Cop 
ilture,

o Park, CA:

Publishing

M. H. (1987)

talk: Notes on

m of

in Pragmatics

iaid-She-Said:

Among Black

I: Indiana

omplishing

Is' play:

nd cooperation

vorking-class

is, L. Pershing,

eminist Theory

149-65. Urbana,

Press.

: Hidden Life of

atus, and

well.

rticipation and

dolescent girls'

arch on Language

1): $353-76$.

e embodiment

d

'interactions.

rdisciplinary

ıgendering

Stokoe and S. A.

in and Gender.

mbridge

n, H. S. (2010)

eth suck, eyeball

zation and stance

it girls'

rnal of Linguistic

$-94$.

atzis, A. (2007)

ildren: Practices

al order among age and Social
Griswold, O. (2007) Achieving authority: Discursive practices in Russian girls' pretend play. Research on Language and Social Interaction 40(4): 291-320.

Gumperz, J. J. (1982) Discourse Strategies. Cambridge: Cambridge University Press.

Gumperz, J. J. and Cook-Gumperz, J. (2005) Making space for bilingual communicative practice. Intercultural Pragmatics 2(1): 1-24.

Henderson, J. (2009) Flirting with Fashion: Anticipatory Socialization in a Tween. Virtual World. Masters Thesis. University of California, Los Angeles.

Howard, K. M. (2009) Breaking in and spinning out: Repetition and decalibration in Thai children's play genres. Language in Society 38(3): 339-63.

Hoyle, S. M. (1998) Register and footing in role play. In S. M. Hoyle and C. T. Adger (eds.), Kids Talk: Strategic Language Use in Later Childhood. 47-67. New York: Oxford University Press.

Hutchby, I. and Moran-Ellis, J. (1998) Introduction. In I. Hutchby and J. Moran-Ellis (eds.), Children and Social Competence: Arenas of Action. 1-25. London: Falmer Press.

Jaffe, A. (2009) Introduction: The sociolinguistics of stance. In A. Jaffe (ed.), Stance: Sociolinguistic Perspectives. 3-28. Oxford: Oxford University Press.

Jorgensen, J. N. (1998) Children's acquisition of code-switching for power-wielding. In P. Auer (ed.), Code-Switching in Conversation: Language, Interaction, and Identity. 237-58. London: Routledge.

Keim, I. (2008) Linguistic variation, style of communication, and sociocultural identity: Case study of a migrant youth group in Mannheim, Germany. In V. Lytra and J. N. Jorgensen (eds.), Multilingualism and Identities Across Contexts: Cross-Disciplinary Perspectives on Turkish-Speaking Youth in Europe. Copenhagen Studies in Bilingualism, Vol. 45. 178-226. Copenhagen, Denmark:
Faculty of Humanities, University of Copenhagen.

Kochman, T. (1983) The boundary between play and nonplay in black verbal dueling. Language in Society 12: 329-37.

Kotthoff, H. (2010) Constructions of the romantic market in girls' talk. In $\mathrm{N}$. Jorgensen (ed.), Current Perspectives in the Study of Youth Language. 43-74.

Frankfurt: Peter Lang.

Köymen, S. B. (2008) 'Use your words': Tying to and commenting on the speech of others in toddlers' peer interactions in. daycare. Paper presented at the American Anthropological Association. San Francisco, CA.

Köymen, S. B. (2010) T said "I don't want him do it" : Toddlers' usage of complement constructions within interactions in daycare. Doctoral Dissertation. University of California, Santa Barbara.

Köymen, S. B. and Kyratzis, A. (2009) Format tying and the acquisition of syntax in toddlers' peer interactions. Proceedings of the 35th Annual Meeting of the Berkeley Linguistics Society. 202-10. Berkeley: Berkeley Linguistics Society.

Kulick, D. (1992) Language Shift and Cultural Reproduction: Socialization, Self, and Syncretism in a Papua New Guinean Village. Cambridge: Cambridge University Press.

Kulick, D. and Schieffelin, B. B. (2004) Language socialization. In A. Duranti (ed.), A Companion to Linguistic Anthropology. 349-68. Malden, MA: Blackwell.

Kyratzis, A. (2004) Talk and interaction among children and the co-construction of peer groups and peer culture. Annual Review of Anthropology 33: 625-49.

Kyratzis, A. (2007) Using the social. organizational affordances of pretend play in American preschool girls' interactions. Research on Language and Social Interaction 40(4): 321-52.

Kyratzis, A. (2010) Latina girls' peer play interactions in a bilingual Spanish- 
English U.S. preschool: Heteroglossia, frame-shifting, and language ideology. Pragmatics 20(4): 557-86.

Kyratzis, A. and Guo, J. (2001) Preschool girls' and boys' verbal conflict strategies in the US and China: Cross-cultural and contextual considerations. Research on Language and Social Interaction 34: 45-74.

Kyratzis, A., Marx, T., and Wade, E. R. (2001) Preschoolers' communicative competence: Register shift in the marking of power in different contexts of friendship group talk. First Language 21: $387-433$.

Kyratzis, A., Reynolds, J., and Evaldsson, A.-C. (2010) Introduction: Heteroglossia and language ideologies in children's peer play interactions. Pragmatics 20(4): 457-66.

Kyratzis, A., Tang, Y.-T., and Köymen, S. B. (2009) Codes, code-switching, and context: Style and footing in peer group bilingual play. Multilingua: Journal of Cross-Cultural and Interlanouage Communication 28(2-3): 265-90.

Labov, W. (1972) Rules for ritual insults. In Language in the Inner City: Studies in the Black English Vernacular. 297-353. Philadelphia, PA: University of Pennsylvania Press.

Li, Wei. (1998) The 'why' and 'how' questions in the analysis of conversational code-switching. In P. Auer (ed.), Code-Switching in Conversation: Language, Interaction, and Identity. 156-76. London: Routledge.

Loyd, H. (2006) Children's use of dialect and theatricality in creating spaces of autonomy and authority in Nicastro, Italy. Paper presented at the American Anthropological Association Annual Meetings. San Jose, CA.

Loyd, H. (2011) Growing up Fast: Girls' Rhetorical Practices of Resilience in Inner City Napoli. Doctoral Dissertation. University of California, Los Angeles.

Mendoza-Denton, N. (2008) Homegirls: Symbolic Practices in the Making of Latina Youth Styles. Oxford: Blackwell.
Minks, A. (2006) Mediated intertextuality in pretend play among Nicaraguan Miskitu children. Texas Linguistic Forum (SALSA) 49: 117-27.

Minks, A. (2010) Socializing heteroglossia among Miskitu children on the Caribbean coast of Nicaragua. Pragmatics 20(4): 495-522.

Mitchell-Kernan, C. and Kernan, K. T. (1977) Pragmatics of directive choice among children. In S. Ervin-Tripp and C. Mitchell-Kernan (eds.), Child Discourse. 189-208. New York: Academic Press.

Morgan, M. (2002) Language, Discourse, and Power in African American Culture. Cambridge: Cambridge University Press.

Nakamura, K. (2001) Gender and language use in Japanese preschool children. Research on Language and Social Interaction 34(1): 15-44.

Newon, L. (2006) Sugar, Spice, and Everything Nice: A Linguistic Study of How Adolescent Girls Formulate Notions of Culture Through Evaluative Commentary. Honors Thesis. Los Angeles, CA: University of California, Los Angeles.

Ochs, E. (1992) Indexing gender. In A. Duranti and C. Goodwin (eds.), Rethinking Context: Language as an Interactive Phenomenon. 335-58. Cambridge: Cambridge University Press.

Ochs, E. (1996) Linguistic resources for socializing humanity. In J. J. Gumperz and S. C. Levinson (eds.), Rethinking Linguistic Relativity. 407-37. Cambridge: Cambridge University Press.

Ochs, E. and Schieffelin, B. B. (1984) Language acquisition and socialization: Three developmental stories and their implications. In R. Shweder and R. LeVine (eds.), Culture Theory: Essays on Mind, Self and Emotion. 276-320. New York: Cambridge University Press.

Ochs, E. and Schieffelin, B. B. (2006) The impact of language socialization on grammatical development. In C. Jourdan and K. Tuite (eds.), Language,
Culture, ani Linguistic $t$ Cambridge Press.

Paugh, A. (2C Children's agency in I Language in

Pomerantz, A disagreeing features of turn shape J. Heritage Action: Stuc 57-101. Car University

Pomerantz, A Conversati relevance a categories i and R. F. Sa of Language Mahwah, $\mathrm{N}$

Pontecorvo, C (2001) Mut: of parentho. dinner conv Development

Poveda, D. an social organ Gitano chilc reproductio] 12(3): 327-4!

Rabain-Jamin, socialization toddlers ins $26(1): 43-65$.

Rampton, B. (1 Ethnicity am Longman.

Rampton, B. (1 Introduction 3/4: 421-7.

Rampton, B. (2 and stylisati

Rampton, B. (2 modernity: In Cambridge, Press. 
rrtextuality raguan istic Forum

teroglossia the

a. Pragmatics

n, K. T.

e choice

Tripp and $C$. ! Discourse. ic Press. iscourse, and Iture. versity Press. nd language iildren. ial Interaction

and Study of ite Notions of ommentary.

, CA:

; Angeles.

ar. In $\mathrm{A}$.

1s.),

as an

38.

versity

urces for

Gumperz

thinking

Cambridge:

(1984)

cialization:

$i$ and their

and $\mathrm{R}$

: Essays on

320.

ersity

(2006) The tion on in

3.), Language,
Culture, and Society: Key Topics in

Linguistic Anthropology. 168-86.

Cambridge: Cambridge University

Press.

Paugh, A. (2005) Multilingual play: Children's code-switching, role play, and agency in Dominica, West Indies. Language in Society 34(1): 63-86.

Pomerantz, A. (1984) Agreeing and disagreeing with assessments: Some features of preferred/dispreferred turn shapes. In J. M. Atkinson and. J. Heritage (eds.), Structures of Social Action: Studies in Conversation Analysis. 57-101. Cambridge: Cambridge University Press.

Pomerantz, A. and Mandelbaum, J. (2005) Conversation analytic approaches to the relevance and uses of relationship categories in interaction. In K. L. Fitch and R. F. Sanders (eds.), Handbook of Language and Social Interaction. 149-71. Mahwah, NJ: Lawrence Erlbaum.

Pontecorvo, C., Fasulo, A., and Sterponi, L. (2001) Mutual apprentices: The making of parenthood and childhood in family dinner conversations. Human Development 44: 340-61.

Poveda, D. and Marcos, T. (2005) The social organization of a 'stone fight': Gitano children's interpretative reproduction of ethnic conflict. Childhood 12(3): 327-49.

Rabain-Jamin, J. (1998) Polyadic language socialization strategy: The case of toddlers in Senegal. Discourse Processes 26(1): 43-65.

Rampton, B. (1995) Crossing: Language and Ethnicity among Adolescents. London: Longman.

Rampton, B. (1999) Styling the other: Introduction. Journal of Sociolinguistics 3/4: 421-7.

Rampton, B. (2003) Hegemony, social class, and stylisation. Pragmatics 13(1): 49-84.

Rampton, B. (2006) Language in late modernity: Interaction in an urban school. Cambridge, UK: Cambridge University Press.
Reynolds, J. F. (2002) Maya children's practices of the imagination: (Dis) playing childhood and politics in Guatemala. Doctoral dissertation. Los Angeles, CA: University of California, Los Angeles.

Reynolds, J. F. (2007) 'Buenos días/ $((\text { military salute }))^{\prime}$ : the natural history of a coined insult. Research on Language and Social Interaction 40(4): 437-65.

Reynolds, J. F. (2008) Socializing puros pericos (little parrots): The negotiation of respect and responsibility in Antonero Mayan sibling and peer networks. Journal of Linguistic Anthropology 18(1): 82-107.

Reynolds, J. F. (2010) Enregistering the voices of discursive authority in Antonero children's socio-dramatic play. Pragmatics 20(4): 467-93.

Rindstedt, C. and Aronsson, K. (2002) Growing up monolingual in a bilingual community: The Quichua revitalization paradox. Language in Society 31: $721-42$.

Rogoff, B. (1981) Adults and peers as agents of socialization: A highland Guatemala profile. Ethos 9: 18-36.

Sacks, H. (1972) On the analyzability of stories by children. In J. J. Gumperz and D. Hymes (eds.), Directions in Sociolinguistics: The Ethnography of Communication. 325-45. New York: Holt, Rinehart and Winston.

Sacks, H. (1995a) On some formal properties of children's games. In Gail Jefferson (ed.), Lectures on Conversation, Vol. I. 489-506. Oxford, UK: Blackwell:

Sacks, H. (1995b) Category-bound activities: 'The baby cried:' Praising, warning, and challenging; tautological proverbs. In G. Jefferson (ed.), Lectures on Conversation, Vol. I. 584-9. Oxford: Blackwell.

Schieffelin, B. B. (1990) The Give and Take of Everyday Life: Lanouage Socialization of Kaluli Children. Cambridge: Cambridge University Press. 
Schieffelin, B. B. (2003) Language and place in children's worlds. Texas Linguistics Forum (SALSA) 45: 152-66.

Schieffelin, B. B. and Ochs, E. (1986) Language Socialization across Cultures. Cambridge: Cambridge University Press.

Schieffelin, B. B. and Ochs, E. (1996) The microgenesis of competence:

Methodology in language socialization. In D. I. Slobin, J. Gerhardt, A. Kyratzis, and J. Guo (eds.), Social Interaction, Socia Context, and Language: Essays in Honor of Susan Ervin-Tripp. 251-63. Mahwah, NJ: Lawrence Erlbaum.

Shankar, S. (2008) Desi Land: Teen Culture, Class, and Success in Silicon Valley. Durham, NC: Duke University Press.

Sheldon, A. (1996) You can be the baby brother, but you aren't born yet: Preschool girls' negotiation for power and access in pretend play. Research on Language and Social Interaction 29(1): 57-80.

Shuman, A. (1986) Storytelling Rights: The Uses of Oral and Written Texts by Urban Adolescents. Cambridge: Cambridge University Press.

Shuman, A. (1992) 'Get outa my face': Entitlement and authoritative discourse. In J. H. Hill and J. T. Irvine (eds.), Responsibility and Evidence in Oral Discourse. 135-60. Cambridge: Cambridge University Press.

Spreckels, J. (2009) 'Now he thinks he's listening to rock music': Identity construction among German teenage girls. In A.-B. Stenstrom and A. M. Jorgensen (eds.), Youngspeak in a Multilingual Perspective. 31-53. Amsterdam: John Benjamins.

Stokoe, E. H. and Smithson, J. (2002) Gender and sexuality in talk-in- interaction: Considering conversation analytic perspectives. In P. Mcllvenny (ed.), Talking Gender and Sexuality. 79-110. Amsterdam, The Netherlands: John Benjamins.

Tarsm, Ş. D. (2007) Turkish Preschool Children's Gender Practices in Peer Play. Master's Thesis. University of California Santa Barbara, CA.

Tarrm, Ş. D. (2008) Tưkish preschool children's gender practices in peer play. Paper presented at the Ninth Biennial Conference of the Center for Language Interaction and Culture. University of California, Los Angeles, CA.

Tetreault, C. (2009) Cité teens entextualizing French TV host register: Crossing, voicing, and participation frameworks. Language in Society 38(2): 201-31.

Tetreault, C. (2010) Collaborative conflicts: Teens performing aggression and intimacy in a French cité. Journal of Linguistic Anthropology 20(1): 72--86.

Thorne, B. (1993) Gender Play: Boys and Girls in School. New Brunswick, NJ: Rutgers University Press.

Vološinov, V. N. (1973) Marxism and the Philosophy of Language. Cambridge, M. A and London: Harvard University Press.

Willis, P. (1981) Learning to Labor: How Working Class Kids Get Working Class Jobs. New York: Columbia University Press.

Zentella, A. C. (1997) Growing Up Bilingual: Puerto Rican Children in New York. Oxford: Blackwell Publishers.

Zimmerman, D. H. (1998) Identity, context, and interaction. In C. Antaki and S. Widdicombe (eds.), Identities in Talk. 87-106. London: Sage.

\section{Language Socialization and Exclusion}

\section{INMACULADA M. GARCÍA-SÁNCHEZ}

\section{Introduction}

Whether one feels a sense of belonging to a particular social group depends to a large extent on the treatment received by others in public domains of social life (Appiah 2006; Levinas 1998; Taylor 1994), specifically whether one is allowed to assume and develop social identities compatible with sanctioned membership in a social group (Ochs 2002). In understanding how children and other novices are apprenticed through language practices and activities into specific childhood identities associated with other community identities that will help them to become competent members of a given social group, language socialization researchers to date have mostly focused on socially organized practices designed to socialize children into ways of acting, feeling, and knowing that are consistent with membership in that social or cultural group (e.g. Ochs and Schieffelin 1984; Schieffelin and Ochs 1986). Little is still known, however, about the socially organized practices that are inconsistent with fully fledged membership in a community and that may render certain groups of novices as 'outsiders' and as a second-class members of the social group. Based on a larger linguistic ethnographic study of Moroccan immigrant children in a rural community in southwestern Spain, this chapter discusses the everyday micro-genesis of social exclusion through the examination of naturally occurring interactions of young Moroccan immigrant children with their Spanish peers and teachers during the school day.

This chapter applies a language socialization perspective on social exclusion by documenting the interactional features of negative differential positioning through which Spanish peers construct marginalized social identities for Moroccan immigrant children. By laying out the linguistic and nonverbal displays that organize the complex architecture of exclusionary acts, activities, and stances, this

The Handbook of Language Socialization, First Edition. Edited by Alessandro Duranti, Elinor Ochs, Bambi B. Schieffelin.

(C) 2011 Blackwell Publishing Ltd. Published 2011 by Blackwell Publishing Ltd. 